\title{
How Do Remuneration Committees Affect Corporate Social Responsibility Disclosure? Empirical Evidence from an International Perspective
}

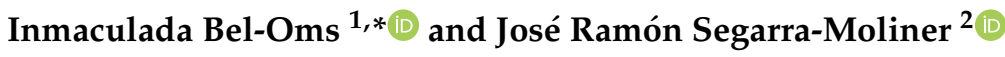 \\ 1 Department of Corporate Finance, Faculty of Economics, University of Valencia, 46022 Valencia, Spain \\ 2 Quality Management, Universitat Jaume I de Castellón, 12071 Castellón, Spain; jsegarra@uji.es \\ * Correspondence: inmaculada.bel@uv.es
}

check for

updates

Citation: Bel-Oms, I.;

Segarra-Moliner, J.R. How Do Remuneration Committees Affect Corporate Social Responsibility Disclosure? Empirical Evidence from an International Perspective. Sustainability 2022, 14, 860. https:// doi.org/10.3390/su14020860

Academic Editors: Ioannis Nikolaou and Mark Anthony Camilleri

Received: 9 November 2021

Accepted: 6 January 2022

Published: 12 January 2022

Publisher's Note: MDPI stays neutral with regard to jurisdictional claims in published maps and institutional affiliations.

Copyright: (c) 2022 by the authors. Licensee MDPI, Basel, Switzerland. This article is an open access article distributed under the terms and conditions of the Creative Commons Attribution (CC BY) license (https:// creativecommons.org/licenses/by/ $4.0 /)$.

\begin{abstract}
The main goal of this study is to analyze whether the existence of remuneration committees tend to disclose more corporate social responsibility (CSR) information. In addition, we test the moderating role played by the proportion of independent directors on boards of directors with the relationship between the constitution of remuneration committees and CSR disclosure. Previous research does not appear to have addressed these questions. The research questions proposed are tested using an international sample of 28,610 listed companies, and we took into consideration information on industrial companies from the Middle East, developed Asian and Pacific countries, both emerging and developed European countries, Africa, Latin America and North America. These findings provide evidence that the existence of remuneration committees is more likely to disclose CSR information, and the existence of independent board members positively moderates the association between the existence of remuneration committees and CSR disclosure. We expand on earlier empirical literature concerning corporate governance and CSR issues.
\end{abstract}

Keywords: remuneration committees; corporate social responsibility; agency theory

\section{Introduction}

The relevant corporate scandals and the recent COVID-19 pandemic have led to a new unprecedented financial context. In this regard, companies have shown interest in both financial performance and social and economic performance, causing corporate social responsibility (CSR) issues to be relevant to academics, investors, regulators and stakeholders.

In a corporate governance environment, the corporate board body improves the transparency of the companies that are increasing the disclosure of CSR information; thus, this is key in financial and non-financial decision-making [1]. Accordingly, CSR is also considered one of the monitor mechanisms to protect investor rights and balance the interests of stakeholders [2] since it mitigates excessive risk avoidance [3]. High engagement of companies in CSR practices could improve shareholder value [3] and enhance the company's reputation, thus enhancing society [4]. Over the past decade, researchers have examined the relationship between CSR disclosure and some characteristics of the corporate governance field, such as board attributes [5], encouragement of corporate efficiency [6], and board composition [7], among others.

However, companies may be pressured from powerful stakeholders to promote CSR disclosure instead of the obtention of incentives [8]. Additionally, firms may have managers whose objective is to use social, environmental, and economic information for their own personal interest, damaging the companies' image and reputation. In this case, firms establish internal mechanisms such as Board sub-committees (audit, corporate governance and nomination and remuneration committees) to ensure the rights of stakeholders. These committees are an important mechanism of the corporate governance research since they protect 
shareholder's interest [9], decide the most important issues of the board of directors [10] and reduce agency problems [11].

Authors such as [12] explained that a remuneration committee is charged with presenting remuneration packages to the corporate boards and to provide this information to stakeholders to reduce agency problems. According to [13] (p. 44), for Spanish listed companies, they must explain that "remuneration committees must have the right expertise and judgement for the complex technical and political task of designing a remuneration system for directors and senior officers that manages to be both fair and efficient. The board should bear these requirements in mind when appointing Committee members and providing them with any advisory resources they need". In line with this, the [14] recommend the constitution separately from the nomination and remuneration committees for the large cap firms. Additionally, this code recommends that most of the members included in this committee should be independent directors. However, the recommendations and laws, which promote the establishment of these committees, depend on each country since individually they each have different good corporate governance codes. These recommendations, based on corporate governance disclosure requirements, are backed under the internationally recognized "comply or explain" regulatory approach, although these recommendations are not laws and regulations. For this reason the existence of a remuneration committee reduces the probability of executives influencing remuneration decisions since this committee acts as an internal mechanism of corporate governance, which determines remuneration policy and improves the transparency by voluntary disclosing information to shareholders [15]. According to the agency theory [16], the remuneration committee act is a mechanism to elaborate upon the executive compensation structure to reduce information asymmetries between disclosing companies and external users and align interests of management and shareholders.

Moreover, compensation committees also influence CSR reports as they execute management action [17]. Indeed, compensation committee decision-making in order to improve corporate disclosure promotes both the reduction in agency issues and the alignment with stakeholder interests. There is an important stream of past evidence based on examining corporate governance, such as board composition (e.g., the proportion of independent directors) and CSR disclosure [5,7]. However, we observe scant empirical evidence regarding the relationship between the constitution of remuneration committees and CSR reporting. In this regard, there is a significant gap in past research which considers the independent directors on the board as moderators of the relationship between remuneration committees and CSR disclosure, however in recent years the role of independent directors as moderators has started to be studied. Authors such as [18] showed that independent boards positively moderated the association between the government, institutional and foreign ownerships, and CSR disclosure. In this way, to the best of our knowledge, there is no past research focused on the exploration of the moderating effect of an independent board in the association between the remuneration committees and the disclosure of CSR information. So, we consider this to be the key contribution of this study.

To summarize, we have tried to answer to the following questions: (i) How do remuneration committees affect CSR disclosure? (ii) Do independent directors on boards moderate the association between the existence of remuneration committees and CSR disclosure? Therefore, the main goal of this manuscript is to examine if the constitution of remuneration committees encourages CSR reporting in a sample of international firms. Moreover, we also test the moderating role played by independent directors on corporate boards on the relationship between the existence of remuneration committees and CSR disclosure, in line with agency theory. Our results denote that the constitution of remuneration committees is positively associated with CSR disclosure. Additionally, the variable independent directors on boards positively moderate the effect of the remuneration committee on the reporting of CSR information.

The results obtained attempt to extend past knowledge by contributing to the debate and removing the large research gaps on CSR disclosure literature. As such, we go beyond 
previous descriptive studies on the existence of remuneration committees through updating analysis and being oriented toward the industry/year. Second, the existing research among corporate governance and CSR bring a better support on the outcomes over how remuneration committees lead to CSR disclosure. To the best of our knowledge, this is the first study to address the impact of remuneration committees on the disclosure of CSR information exclusively, and to examine the moderating role of board independence on this association. Our results find that the positive effect of remuneration committees on CSR disclosure is negatively moderated by board independence. Thus, it is reasonable to presume that the analysis of the association between the constitution of remuneration committees on CSR disclosure and the moderating role played by board independence will enhance past research beyond existing assumptions and create new lines of investigation for further research.

The rest of the paper is organized as follows: Section 2 presents past research and develops hypotheses. Section 3 describes the empirical design. Section 4 reports results obtained in this research and, finally, Section 5 offers conclusions, limitations and future lines of research.

\section{Theoretical Background and Hypotheses}

The agency theory is the most frequently used theory to explore the relationship between corporate governance, such as board attributes, and the reporting of CSR information (e.g., [19-21]. This approach posits that principals allow agents to manage business operations on their behalf [22] and this act may generate a divergence of interests between the parties, and ultimately, the existence of information asymmetries. For this reason, shareholders need to develop internal or external control mechanisms for monitoring managers to reduce information gaps and possible agency costs. The board of directors is a relevant corporate governance mechanism since their main function is monitoring and linking companies with their external context [23]. Consequently, corporate boards can delegate some of their powers to committees, such as the audit committee, nominating committee, remuneration committee, CSR committee or corporate governance committee, who are responsible for a particular area that enhances the oversight and control of management, accomplished with the expectations and interests of shareholders and a reduction in agency problems [24]. Agency perspective suggests that inclusion on delegate committees strengthens the monitoring mechanisms needed to control management between the separation of principal and agents of firms [16]. Ref. [25] noted that the quality of the activities of corporate boards is increased by the delegation of functions to specific committees. Consistent with agency theory, the remuneration committee is the most important for incentivizing management to work, helping to mitigate agency problems and ensuring better alignment to stakeholders' interests, which in turn improves corporate disclosure. Ref. [21] determine that the remuneration committees are essential in the remuneration of senior company officers, which is associated with higher firm performance and as a consequence, higher CSR disclosure. In this sense, Ref. [26] showed that remuneration committees tend to voluntarily disclosure attribution and higher levels of information when increasing the quality of this committee. In relation to the disclosure of environmental, social and governance information, the remuneration committee encourages the disclosure in Thai listed companies [27]. In this sense, Ref. [28] provide evidence that the remuneration committee influences the narrative human capital disclosure in the Colombo Stock Exchange. In contrast, authors such as [29] suggested that a remuneration committee that is too large can be less effective in their functions, which leads to reduced CSR disclosure. Apart from the constitution of remuneration committees, owners believe that investment in CSR practices will reduce the market frictions and agency problems [20]. Agency theory posits that the board of directors is considered a relevant mechanism to encourage CSR issues [1] and the board's attributes improve CSR disclosure, reducing information asymmetry and mitigating agency costs [19]. 
We argue that the constitution of remuneration committees would mitigate agency problems and enhance the CSR disclosure with implications for firm survival. Drawing on the agency theory and in the context of the remuneration committees in international firms, we develop our hypotheses below.

\subsection{Remuneration Committees and CSR Disclosure}

The remuneration committee is a common committee recommended by the corporate governance codes applicable to listed firms across countries. This committee establishes policy on remuneration taking into account business size, performance record and prospects, type of industry or sector, cashflow and debt levels, key performance measures, as well as internationalization, complexity and innovation. In order to be effective, it used to determine and recommend reward policy that attracts and motivates CEOs to achieve goals that are in the long-term interests of shareholders. Essentially, the remuneration committee is as important as the audit committee in the corporate governance structure, and may reduce agency problems concerning CEO compensation issues by improving the alignment of executive remuneration packages with firm value [30]. Ref. [31] recommended that the remuneration committee should include a majority of non-executive directors to improve independent decision-making about executive pay, among other decisions. [15] provide evidence that the remuneration committee promotes transparency in setting the remuneration of senior executives and participates in the decision-making about forward-looking activities rather than monitoring historical activities. Past research analyzes the association between the presence of a remuneration committee and some factors of corporate governance, such as the use of incentive-based compensation [32], corporate failure [33], performance [21], financial reporting quality [34], CEO pay [35], and narrative human capital disclosure [28], among others.

The role of the board of directors and audit committees on CSR disclosure has become a relevant issue today [36]. However, not many studies are based on the role of the remuneration committee in the disclosure of non-financial information. Past research [35] shows that companies that include large remuneration committees tend to disclose more specific details about their activities to users of the annual reports. Ref. [35] demonstrated in their study of Australian companies that the compensation committee tends to disclose voluntary information remunerations. Correspondingly, Ref. [29] noted that larger committee size positively promotes CSR disclosure, and [17] provide evidence that the number of members of the remuneration committee positively influence the assurance statement to the sustainability report. Ref. [37] show that the compensation committee may be in a good position to evaluate the carbon risks, and consequently, may improve corporate carbon performance. Ref. [27] argue that the inclusion of board sub-committees such as remuneration committees in Thai listed companies encourage the disclosure of environmental, social and governance information, in line with agency theory.

Past literature shows the effect of CSR disclosure on corporate governance mechanisms, however there is a scant amount of literature focused on examining the association between the constitution of remuneration committees and the reporting of CSR information. As such, the impact of using the remuneration committees in companies for CSR disclosure needs to be examined. The following hypothesis is tested in this study:

Hypothesis 1 (H1). The existence of a remuneration committee is positively associated with CSR disclosure.

\subsection{The Moderating Role of Independent Directors}

Previous literature analyzes the relationship between independent directors and some aspects of corporate governance [38]. Agency perspective postulates that independent directors are more effective in monitoring management to protect shareholders' interests [21,39]. Most of these studies demonstrate that independent directors are considered an essential mechanism in the corporate governance field, since their main function is based on 
monitoring and advisory functions [40]. Ref. [16] suggested that independent directors tend to comply with the law and uphold minority stakeholders' interests, in contrast with the executive directors who have a lower motivation to comply with shareholders' interests [38]. Moreover, the independent directors are more likely to encourage strategic change when a company lowers its performance [41], and they contribute positively when companies must change to survive [42]. For this reason, independent directors are riskaverse, protect the firm's reputation [43] and are more objective in the decision-making process [44]. The Code of Corporate Governance and regulators recommend the inclusion of independent directors on the board of directors, since it has a positive effect on firm values [45] and ethical practice [46]. In this sense, reference [47] evidence that firms with a higher proportion of independent directors used to implementing more socially responsible activities, due to having become aware of their responsibility towards the environment and social necessities [48]. Ref. [49] find that companies with independent directors tend to disclose environmental, social and governance information. Refs. [36,50] show in their respective works that the independent directors have a positive effect on CSR disclosure, and reference [51] also demonstrates that independent directors could play a positive role in enhancing the disclosure of CSR quality. Ref. [5] documented that board independence positively influences CSR disclosure in countries with scant commitment to sustainable goals. Ref. [52] documented that the independent boards can influence the decisions' remuneration committee in relation to CSR disclosure.

However, it would appear that the moderating influence of independent directors on boards on the association between the constitution of the remuneration committee and CSR disclosure has not been examined in the past. Therefore, the effect of the independent director's impact on CSR reporting when interacting with the remuneration committee merits our attention. The coexistence of the remuneration committees with a higher proportion of independent directors is expected to positively affect CSR disclosure. Companies with remuneration committees will be more likely to disclose CSR information to provide a greater commitment to stakeholders' interests, not just concerning financial information. Ref. [18] documented that a high level of board independence positively moderates institutional, government and foreign investors on CSR disclosure. Furthermore, the independent directors may act to enhance the financial and economic orientations instead of non-financial orientations, which may negatively impact stakeholder interests and society.

According to the arguments above, we postulate that a higher proportion of independent directors on boards will positively moderate the association between the constitution of remuneration committees and CSR reporting. Thus, we offer the following hypothesis:

Hypothesis 2 (H2). The independent board moderates the relationship between the existence of a remuneration committee and CSR disclosure.

Based on the aforementioned arguments, this study shows that the association between the constitution of the remuneration committee and CSR reporting is shaped by independent directors on boards, as noted in Figure 1. 


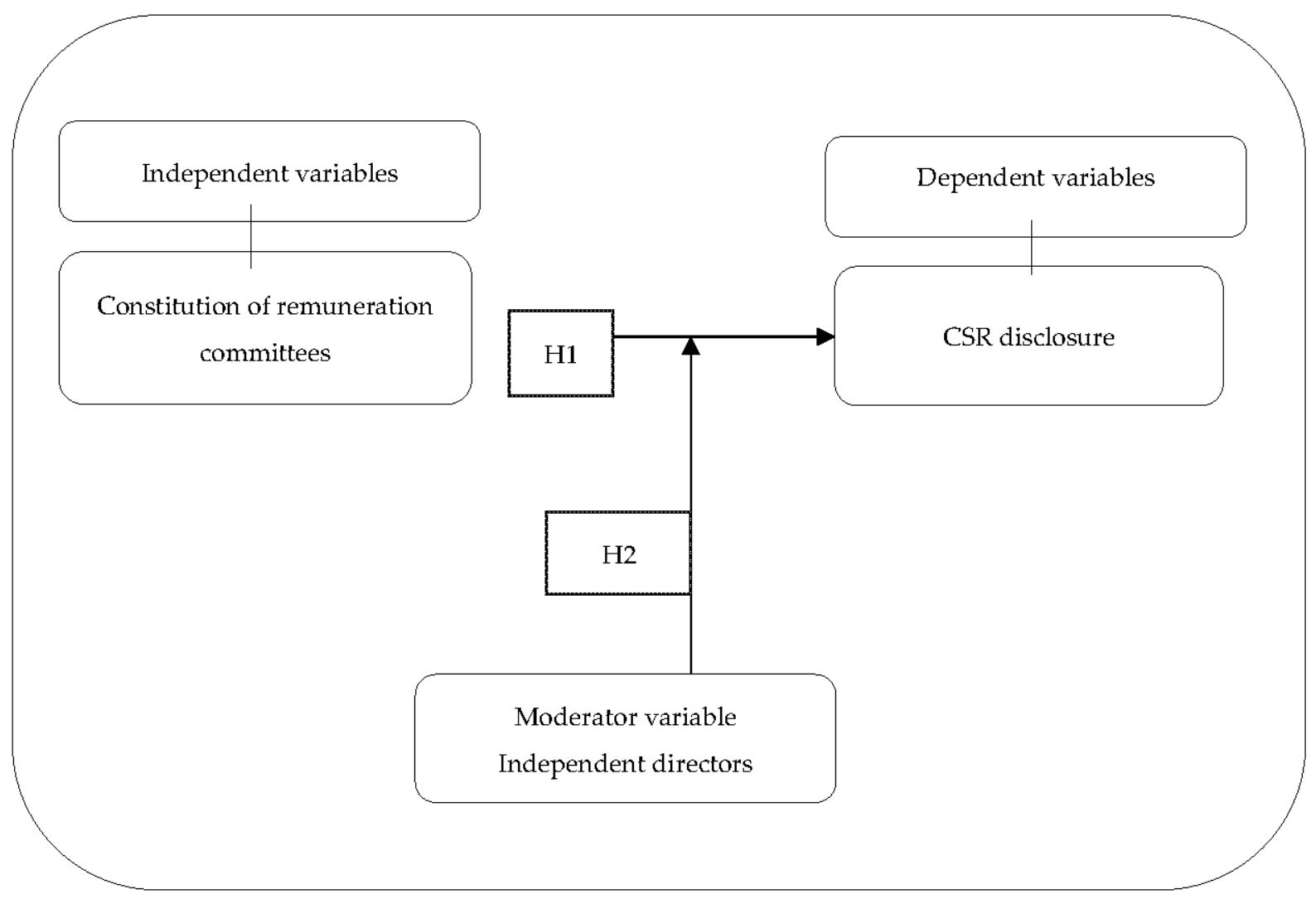

Figure 1. Analytical Framework.

\section{Research Method}

\subsection{Sample}

The original sample includes 28,610 international industrial firms collected from the Thomson Reuters database from 2018, the year from which this database has provided corporate governance, financial information and economic. We have used the industrial sector as it plays a very significant role in the global economy. Some companies have been excluded from the initial sample as they were bankrupt or mergers. Therefore, we obtained 28,614 firm-year observations in 27 countries (Australia, Austria, Belgium, Brazil, Canada, Chile, China, Denmark, Finland, France, Germany, Hong Kong, India, Ireland, Italy, Japan, Mexico, Netherlands, New Zealand, Norway, Portugal, Spain, Sweden, Switzerland, Thailand, United Kingdom, United States).

\subsection{Variables}

The dependent variable is corporate social responsibility and is defined as CSR_INDEX. The measure of the variable CSR is calculated in different ways as shown by [53]. In line with past research [54,55], our variable CSR index is measured using a multidimensional construct to capture all environmental, economic, and social issues disclosed by firms. Here, CSR is captured by the ratio between the aggregation of 140 items focused on environmental, social and economic issues and the total number of items, which codes as 1 if the firm disclose the CSR information related each item, and $0[7,56]$.

We have used the following independent variables. The independent variable, constitution of remuneration committee (RC_P), takes a value of 1 if a remuneration committee exists in the firm or 0 otherwise [21,26]. Our moderating variable is board independence (PBIND) and is calculated as the ratio between the total number of independent members on boards and the total number of board members [21,26,37,44].

In order to avoid biased results, we use four control variables traditional in remuneration committee research $[21,26,37]$. The variable female directors on boards (FEMD_BOARD) 
is the first control variable considered and is measured as a Dichotomous variable that codes as 1 if the board of directors have female directors, and 0 otherwise [57]. In this sense, the inclusion of female directors on corporate boards may provide different opinions and points of views, which lead to improved business creativity [58]. For this reason, in line with previous empirical studies this variable has shown a positive association with disclosure of CSR information $[59,60]$. The second control variable included in the model is the duality of CEO (CEO_DUALITY), measured as a dichotomous indicator that codes as 1 when the CEO of the company is the chairperson of the board, and 0 otherwise [26]. Previous literatures are contradictory in their outcomes. Some authors provide evidence that there is a positive relationship between CEO duality and CSR disclosure [61,62], while other authors demonstrated a negative association $[63,64]$. The last control variable is the firm size (LTA), calculated as the logarithm of total assets [21,26,37]. In this regard, authors such as [65], and reference [66] show a positive link between firm size and CSR disclosure as large firms have greater social pressure and are consequently more predisposed to adopt CSR practices. Table 1 presents the variables description.

Table 1. Variables Description.

\begin{tabular}{|c|c|}
\hline Variables & Description \\
\hline CSR_INDEX & $\begin{array}{l}\text { The ratio between the aggregation of } 140 \text { items } \\
\text { focused on environmental, social and economic } \\
\text { issues and the total number of items analyzed, } \\
\text { which codes as } 1 \text { if the firm disclose the CSR } \\
\text { information related each item, and } 0\end{array}$ \\
\hline RC_P & $\begin{array}{l}\text { This variable takes a value of } 1 \text { if a } \\
\text { remuneration committee existence in the firm } \\
\text { or } 0 \text { otherwise }\end{array}$ \\
\hline PBIND & $\begin{array}{l}\text { Ratio between total number of independent } \\
\text { directors on boards on total number of } \\
\text { directors on boards }\end{array}$ \\
\hline FEM_BOARD & $\begin{array}{l}\text { Dichotomous variable that codes as } 1 \text { if the } \\
\text { board of directors have female directors, and } \\
0 \text { otherwise }\end{array}$ \\
\hline CEO_DUALITY & $\begin{array}{l}\text { Dichotomous indicator that codes as } 1 \text { when } \\
\text { the CEO of the company is the chairperson of } \\
\text { the board, and } 0 \text { otherwise }\end{array}$ \\
\hline LTA & The log of total assets \\
\hline
\end{tabular}

\subsection{Regression Model Specification}

To check our hypotheses, the following model is estimated through the generalized method of moments (GMM) to avoid the endogeneity bias:

$$
\begin{aligned}
& \text { CSR_INDEXit }=\beta 0+\beta 1 R C \_P i t+\beta 2 P B I N D i t+\beta 3 R C \_P \times \text { PBINDit }+\beta 4 \text { FEM_BOARDit }+\beta 5 \text { CEO_DUAL- } \\
& \text { ITYit }+\beta 6 \text { LTAit }+\sum \beta j \text { YEARt }+U i+{ } j
\end{aligned}
$$

This model estimates the parameters incorporated, with each firm being indicated by $\mathrm{i}$ and the time period indicated by $t$. Additionally, it comprises a firm-specific effect, named ðit, which controls the unobservable heterogeneity of what is related to firm decisionmaking as well as Uit, which is referred to as the disturbance term. As mentioned above, this model is estimated using GMM to counter the endogeneity problems caused by unobservable heterogeneity, dynamic endogeneity and simultaneity. Additionally, this model needs to include the lagged dependent variable to account for the possibility that contemporaneous ratios of female directors on the board are a function of past leverage [67]. The GMM allows us to control the individual effect (Uit) and time heterogeneity (ðit). The second-order serial correlation tests (m2) show that there is, or not, an absence of a 
correlation between the residuals in first differences. Additionally, the Hansen test provides evidence of the adequacy of the tools used in the absence of correlation between the instruments and the random disturbance.

\section{Results}

\subsection{Descriptive Statistics}

Descriptive statistics are illustrated in Table 2 (mean and standard deviation) for all the analyzed variables in the model analysis. The level of the CSR information disclosed stands at an average of $19.90 \%$ of the 140 items tested in the CSR index. Moreover, the mean presence of RC_P is 7\%, and the boards have approximately 5\% of PBIND. Regarding control variables, on average, the proportion of FEM_BOARD is 5\%, the presence of CEO_DUALITY is $2 \%$ and LTA is $10.36 \%$.

Table 2. Descriptive Statistics.

\begin{tabular}{lccc}
\hline \multicolumn{1}{c}{ Variable } & Obs. & Mean & Standard Deviation \\
\hline CSR_INDEX & 343.356 & 1.99 & 7.765 \\
RC_P & 343.356 & 0.07 & 0.252 \\
PBIND & 343.356 & 0.05 & 0.217 \\
FEM_BOARD & 343.356 & 0.05 & 0.221 \\
CEO_DUALITY & 343.356 & 0.02 & 0.150 \\
LTA & 343.356 & 10.36 & 9.840 \\
\hline
\end{tabular}

The correlation matrix is reported in Table 3. In this table, there are no high values for the coefficients between the dependent, independent variables and the control variables, in line with [68]. For this reason, we confirm the absence of multicollinearity problems among all variables for this regression model.

Table 3. Correlation Matrix.

\begin{tabular}{|c|c|c|c|c|c|c|}
\hline & CSR_INDEX & RC_P & PBIND & FEM_BOARD & CEO_DUALITY & LTA \\
\hline CSR_INDEX & 1.000 & & & & & \\
\hline RC_P & 0.484 & 1.000 & & & & \\
\hline PBIND & 0.524 & 0.573 & 1.000 & & & \\
\hline FEM_BOARD & 0.548 & 0.638 & 0.677 & 1.000 & & \\
\hline CEO_DUALITY & 0.329 & 0.416 & 0.433 & 0.458 & 1.000 & \\
\hline LTA & 0.119 & 0.068 & 0.106 & 0.101 & 0.548 & 1.000 \\
\hline
\end{tabular}

\subsection{Regressions Analysis}

Table 4 presents the findings of the estimated regression model as proposed, and the moderating effect of the independent directors on corporate boards. In Model 1, the variable RC_P presents a positive sign and is statistically significant. Thus, hypothesis 1 cannot be rejected. This finding supports the view that the constitution of remuneration committees has a positive effect on CSR disclosure, consistent with [29], and [17], A, who also provide this evidence. This implies that the existence of remuneration committees in companies makes firms' decisions regarding non-financial and financial information effective. One possible explanation is that firms adopting the constitution of remuneration committees have a better CSR information system, which facilitates the effective implementation of sustainability practices. The positive impact can be explained on the basis that companies do not have pressure from their shareholders to maximize the shareholder value as the main objective, which enable them to focus on social, environmental and economic perspectives. 
Table 4. Multivariate analysis results of the Generalized Method of Moments.

\begin{tabular}{lcc}
\hline & $\begin{array}{c}\text { MODEL } \mathbf{1} \\
\text { Coef. } \\
\mathbf{P}>\mathbf{| t |} \mid\end{array}$ & $\begin{array}{c}\text { MODEL 2 } \\
\text { Coef. } \\
\mathbf{P}>|\mathbf{t}|\end{array}$ \\
\hline CSR_INDEX $\left({ }_{\mathrm{t}-1}\right)$ & 0.28 & 0.24 \\
RC_P & 5.10 & 6.67 \\
RC_P $\times$ PBIND & & -5.85 \\
PBIND & 8.16 & 11.49 \\
FEM_BOARD & 9.35 & 8.99 \\
CEO_DUALITY & 1.84 & 1.75 \\
LTA & 0.04 & 0.04 \\
\hline Year effects & Yes & Yes \\
Wald $\chi^{2}$ test & 5144.05 & 4884.80 \\
\hline
\end{tabular}

Model 2 analyzes the moderating effect of independent directors on boards on the relationship between the constitution of remuneration committees and CSR disclosure. The coefficients of the crossover effects that contrast this hypothesis (RC_P $\times$ PBIND), as well as the main variable (RC_P), show high statistical significance (at $1 \%$ ) and do not present the expected sign. These coefficients are just the opposite sign, that is, negative, and this means that as the proportion of independent directors on boards grows, the negative relationship established empirically between the remuneration committee and CSR disclosure increases. In this regard, the existence of this type of committee would reduce CSR disclosure and, if the proportion of independent directors on the board at the same time increased, CSR disclosure would decrease even more, contradicting what was expected. Thus, we reject the second hypothesis, and we conclude that the proportion of independent directors on corporate boards negatively moderates the association between the existence of remuneration committees and disclosure of CSR information, which supports the premise that board independence encourages CSR disclosure in countries with scant commitment to sustainable goals [5]. Another explanation could be that board independence may improve financial orientations instead of non-financial orientations, which may negatively impact stakeholder interests and society and may create the illusion of effectively controlling management behavior [69]. This finding suggests that both board independence and the constitution of remuneration committees are mechanisms of corporate governance, however when coexisting simultaneously, they have a negative influence on the reporting of CSR information.

The control variables FEM_BOARD, CEO_DUALITY and LTA present a positive and significant sign, as expected. These results also note that larger companies, with female directors on boards, and those with CEO duality, present a positive effect on CSR disclosure.

\section{Conclusions}

The purpose of this article was to examine the association between the constitution of remuneration committees and CSR disclosure, controlling for the female directors on boards, the duality of CEO directors and firm size. A major strength of this study is that it analyzes the moderating role played by the proportion of independent directors on board of directors on the association between the existence of remuneration committees and CSR disclosure.

Our results show that the constitution of remuneration committees encourages the disclosure of CSR information. We also find that board independence negatively moderates the relationship between the existence of remuneration committees and CSR disclosure. The cohabitation of remuneration committees and board independence can produce a negative influence on CSR disclosure since their orientation may be focused on financial orientation instead of non-financial as CSR issues.

Our findings have a number of policy implications. First, the results of this article also highlight the need to extend previous literature focused on agency theory since we develop 
how board independence moderates the relationship between the existence of remuneration committees and CSR disclosure. Past empirical studies examined the elements that have an effect on CSR disclosure, however there is no previous research on the moderating effect of board independence on the existence of the remuneration committee and the disclosure of CSR information. Second, by highlighting the importance of the moderating effect of board independence on board committees and CSR disclosure, and contributing to the gap in the earlier research, this study motivates and inspires scholars to conduct comparative research in this area. Third, the findings of this research offer an implication to regulatory bodies. The findings reveal that the implementation of the constitution of remuneration committees in companies is likely to improve CSR reporting. Nevertheless, the interaction between the constitution of remuneration committees and board independence has a negative impact on the reporting of CSR information. Therefore, these results are useful for companies and managers whose goals are based on non-financial information disclosure to engage with stakeholder needs and demands, and will have to decide whether to implement the constitution of remuneration committees or improve board independence. Fourth, this study has practical implications as the remuneration committee facilitates the knowledge transfer of CSR information to the board who makes decisions about the activities and practices the company can utilize. However, the moderator effect on the independent directors on boards reduces the transfer of this information since they are more focused on specific and economic decisions. This study also has implications for those responsible for preparing the integrated reports that determine the inclusion of information on CSR as companies are currently under pressure from the EU's indications on social and environmental issues. The disclosure of CSR information depends on government regulatory approaches and the use of voluntary performance measures [70]. For this reason, these practitioners should establish standards and procedures, which may be requirements rather than just recommendations, to comply, regulate and implement social, environmental, and economic actions. Our results reinforce the theoretical and empirical rationalities suggested by agency theory regarding the importance of the companies' inclusion of financial and non-financial information in their reports [71].

The findings obtained by research must be carefully analyzed considering the following limitations and proposed future research. First, regarding limitations, it should be noted that our study only examined 2018's information disclosure on industrial companies from the Middle East, developed Asian and Pacific countries, both emerging and developed European countries, Africa, Latin America and North America and, as such, may not be applicable across other periods and industries. Consequently, in order to assert whether our findings are consistent over time and replicable across all industries, we believe that a more detailed study across later years and industries of corporate governance and CSR disclosures would further develop the results of this manuscript. We also note that our corporate governance variable, the existence of remuneration committees, simply ranks the firms in our sample by their existence or not; i.e., we do not have any absolute measure of a company's remuneration committee quality.

There are several other specific areas that future research could also usefully explore. Future research might consider constructing the absolute variable of the existence of remuneration committees to examine the impact of this new variable on the disclosure of CSR information. Finally, it would be interesting to study the moderating role played by board independence on the relationship between the constitution of all board committees on CSR disclosure and their impact on the commitment with stakeholders' interests and needs.

Author Contributions: Conceptualization, I.B.-O. and J.R.S.-M.; methodology, I.B.-O. and J.R.S.-M.; software, I.B.-O. and J.R.S.-M.; investigation, I.B.-O. and J.R.S.-M.; writing-original draft preparation, I.B.-O. and J.R.S.-M.; writing-review and editing I.B.-O. and J.R.S.-M.; supervision, I.B.-O. and J.R.S.-M. All authors have read and agreed to the published version of the manuscript.

Funding: This research received no external funding.

Institutional Review Board Statement: Not applicable. 


\section{Informed Consent Statement: Not Applicable.}

Data Availability Statement: Data is contained within the article.

Conflicts of Interest: The authors declare no conflict of interest.

\section{References}

1. Jamali, D.; Safieddine, A.; Rabbath, M. Corporate governance and corporate social responsibility synergies and interrelationships. Corp. Gov. Int. Rev. 2008, 16, 443-459. [CrossRef]

2. Mason, C.; Simmons, J. Embedding corporate social responsibility in corporate governance: A stakeholder systems approach. J. Bus. Ethics 2014, 119, 77-86. [CrossRef]

3. Harjoto, M.; Laksmana, I. The impact of corporate social responsibility on risk taking and firm value. J. Bus. Ethics 2018, 151, 353-373. [CrossRef]

4. Martínez-Ferrero, J.; Rodríguez-Ariza, L.; García-Sánchez, I.M.; Cuadrado-Ballesteros, B. Corporate social responsibility disclosure and information asymmetry: The role of family ownership. Rev. Manag. Sci. 2018, 12, 885-916. [CrossRef]

5. Guerrero-Villegas, J.; Pérez-Calero, L.; Hurtado-González, J.M.; Giráldez-Puig, P. Board attributes and corporate social responsibility disclosure: A meta-analysis. Sustainability 2018, 10, 4808. [CrossRef]

6. Xie, J.; Nozawa, W.; Yagi, M.; Fujii, H.; Managi, S. Do environmental, social, and governance activities improve corporate financial performance? Bus. Strategy Environ. 2019, 28, 286-300. [CrossRef]

7. Gallego-Álvarez, I.; Pucheta-Martínez, M.C. Corporate social responsibility reporting and corporate governance mechanisms: An international outlook from emerging countries. Bus. Strategy Dev. 2020, 3, 77-97. [CrossRef]

8. Khan, A.; Muttakin, M.B.; Siddiqui, J. Corporate governance, and corporate social responsibility disclosures: Evidence from an emerging economy. J. Bus. Ethics 2013, 114, 207-223. [CrossRef]

9. Harrison, J.R. The Strategic Use of Corporate Board Committees. Calif. Manag. Rev. 1987, 30, 109-125. [CrossRef]

10. Sherman, H.; Beldona, S.; Joshi, M. Institutional investor heterogeneity: Implications for strategic decisions. Corp. Gov. Int. Rev. 1998, 6, 166-173. [CrossRef]

11. Tao, N.B.; Hutchinson, M. Corporate governance and risk management: The role of risk management and compensation committees. J. Contemp. Account. Econ. 2013, 9, 83-99. [CrossRef]

12. Williamson, O.E. Credible commitments: Using hostages to support exchange. Am. Econ. Rev. 1983, 73, 519-540.

13. Unified Good Governance Code of Listed Companies; Comisión Nacional del Mercado de Valores: Madrid, Spain, 2006. Available online: https: / / www.cnmv.es/DocPortal/Publicaciones/CodigoGov/Codigo_unificado_Ing_04en.pdf (accessed on 8 November 2021).

14. Good Governance Code of Listed Companies; Comisión Nacional del Mercado de Valores: Madrid, Spain, 2020. Available online: https://www.cnmv.es/DocPortal/Publicaciones/CodigoGov/CBG_2020_ENen.PDF (accessed on 8 November 2021).

15. Conyon, M.; Peck, S. Board control, remuneration committees, and top management compensation. Acad. Manag. J. 1998, 41, 146-157.

16. Fama, E.F.; Jensen, M.C. Separation of ownership and control. J. Law Econ. 1983, 26, 301-325. [CrossRef]

17. Rahmania, M.; Septiani, A. Pengaruh karakteristik tata kelola dan karakteristik perusahaan terhadap keputusan perusahaan terkait sustainability reporting. Diponegoro J. Account. 2019, 8, 1-13.

18. Zaid, M.A.; Abuhijleh, S.T.; Pucheta-Martínez, M.C. Ownership structure, stakeholder engagement, and corporate social responsibility policies: The moderating effect of board independence. Corp. Soc. Responsib. Environ. Manag. 2020, 27, 1344-1360. [CrossRef]

19. Rao, K.; Tilt, C. Board composition and corporate social responsibility: The role of diversity, gender, strategy and decision making J. Bus. Ethics 2016, 138, 327-347. [CrossRef]

20. Samet, M.; Jarboui, A. CSR, agency costs and investment-cash flow sensitivity: A mediated moderation analysis. Manag. Financ. 2017, 43, 299-312. [CrossRef]

21. Harymawan, I.; Agustia, D.; Nasih, M.; Inayati, A.; Nowland, J. Remuneration committees, executive remuneration, and firm performance in Indonesia. Heliyon 2020, 6, e03452. [CrossRef] [PubMed]

22. Jensen, M.C.; Meckling, W.H. Theory of the firm: Managerial behavior, agency costs and ownership structure. J. Financ. Econ. 1976, 3, 305-360. [CrossRef]

23. Carter, D.A.; D'Souza, F.; Simkins, B.J.; Simpson, W.G. The gender and ethnic diversity of US boards and board committees and firm financial performance. Corp. Gov. Int. Rev. 2010, 18, 396-414. [CrossRef]

24. Boone, A.L.; Mulherin, J.H. How do Corporate Boards Balance Monitoring and Advising? The Situational Use of Special Committees in Corporate Takeovers. The Situational Use of Special Committees in Corporate Takeovers (27 November 2012). Available online: https:/ / ssrn.com/abstract=1783064 (accessed on 8 November 2021).

25. Ruigrok, W.; Peck, S.; Tacheva, S.; Greve, P.; Hu, Y. The determinants and effects of board nomination committees. J. Manag. Gov. 2006, 10, 119-148. [CrossRef]

26. Kanapathippillai, S.; Mihret, D.; Johl, S. Remuneration committees and attribution disclosures on remuneration decisions: Australian evidence. J. Bus. Ethics 2019, 158, 1063-1082. [CrossRef] 
27. Suttipun, M. The influence of board composition on environmental, social and governance (ESG) disclosure of Thai listed companies. Int. J. Discl. Gov. 2021, 18, 391-402. [CrossRef]

28. Abeysekera, I. Role of remuneration committee in narrative human capital disclosure. Account. Financ. 2012, 52, 1-23. [CrossRef]

29. Alotaibi, K. Determinants and Consequences of CSR Disclosure Quantity and Quality: Evidence from Saudi Arabia. Ph.D. Thesis, Faculty of Business, Plymouth University, Plymouth, UK, 2016.

30. Murphy, K.J. Corporate performance and managerial remuneration: An empirical analysis. J. Account. Econ. 1985, 7, 11-42. [CrossRef]

31. Cadbury, A. Report of the Committee on the Financial Aspects of Corporate Governance; Gee Publishing: London, UK, 1992.

32. Laux, C.; Laux, V. Board committees, CEO compensation, and earnings management. Account. Rev. 2009, 84, 869-891. [CrossRef]

33. Appiah, K.O.; Chizema, A. Remuneration committee and corporate failure. Corp. Gov. 2015, 15, 623-640. [CrossRef]

34. Kusnadi, Y.; Leong, K.S.; Suwardy, T.; Wang, J. Audit committees and financial reporting quality in Singapore. J. Bus. Ethics 2016, 139, 197-214. [CrossRef]

35. Kanapathippillai, S.; Johl, S.K.; Wines, G. Remuneration committee effectiveness and narrative remuneration disclosure. Pac. Basin Financ. J. 2016, 40, 384-402. [CrossRef]

36. Fernández-Gago, R.; Cabeza-García, L.; Nieto, M. Independent directors' background and CSR disclosure. Corp. Soc. Responsib. Environ. Manag. 2018, 25, 991-1001. [CrossRef]

37. Haque, F.; Ntim, C.G. Executive compensation, sustainable compensation policy, carbon performance and market value. Br. J. Manag. 2020, 31, 525-546. [CrossRef]

38. Ozkan, N. Do corporate governance mechanisms influence CEO compensation? An empirical investigation of UK companies. J. Multinatl. Financ. Manag. 2007, 17, 349-364. [CrossRef]

39. Tibiletti, V.; Marchini, P.L.; Furlotti, K.; Medioli, A. Does corporate governance matter in corporate social responsibility disclosure? Evidence from Italy in the "era of sustainability". Corp. Soc. Responsib. Environ. Manag. 2020, 28, 896-907. [CrossRef]

40. Zahra, S.A.; Pearce, J.A. Boards of directors and corporate financial performance: A review and integrative model. J. Manag. 1989, 15, 291-334. [CrossRef]

41. Daily, C.M.; Dalton, D.R. Corporate governance and the bankrupt firm: An empirical assessment. Strateg. Manag. J. 1994, 15, 643-654. [CrossRef]

42. Weisbach, M.S. Outside directors and CEO turnover. J. Financ. Econ. 1988, 20, 431-460. [CrossRef]

43. Zaman, R.; Bahadar, S.; Kayani, U.N.; Arslan, M. Role of media and independent directors in corporate transparency and disclosure: Evidence from an emerging economy. Corp. Gov. Int. J. Bus. Soc. 2018, 18, 858-885. [CrossRef]

44. Saona, P.; Muro, L.; Alvarado, M. How do the ownership structure and board of directors' features impact earnings management? The Spanish case. J. Int. Financ. Manag. Account. 2020, 31, 98-133. [CrossRef]

45. Fuzi, S.F.S.; Halim, S.A.A.; Julizaerma, M.K. Board independence and firm performance. Procedia Econ. Financ. 2016, 37, 460-465. [CrossRef]

46. Giraldez, P.; Hurtado, J.M. Do independent directors protect shareholder value? Bus. Ethics Eur. Rev. 2014, 23, 91-107. [CrossRef]

47. Harjoto, M.A.; Jo, H. Corporate governance and CSR nexus. J. Bus. Ethics 2011, 100, 45-67. [CrossRef]

48. Ibrahim, N.A.; Howard, D.P.; Angelidis, J.P. Board members in the service industry: An empirical examination of the relationship between corporate social responsibility orientation and directional type. J. Bus. Ethics 2003, 47, 393-401. [CrossRef]

49. Husted, B.W.; de Sousa-Filho, J.M. Board structure and environmental, social, and governance disclosure in Latin America. J. Bus. Res. 2019, 102, 220-227. [CrossRef]

50. Jizi, M. The influence of board composition on sustainable development disclosure. Bus. Strategy Environ. 2017, 26, 640-655. [CrossRef]

51. Habbash, M. Corporate governance and corporate social responsibility disclosure: Evidence from Saudi Arabia. Soc. Responsib. J. 2016, 12, 740-754. [CrossRef]

52. Chhaochharia, V.; Grinstein, Y. CEO compensation and board structure. J. Financ. 2009, 61, 231-261. [CrossRef]

53. Gray, R.; Kouhy, R.; Lavers, S. Corporate social and environmental reporting: A review of the literature and a longitudinal study of UK disclosure. Account. Audit. Account. J. 1995, 8, 47-77. [CrossRef]

54. Lee, Y.K.; Kim, Y.S.; Lee, K.H.; Li, D. The impact of CSR on relationship quality and relationship outcomes: A perspective of service employees. Int. J. Hosp. Manag. 2012, 31, 745-756. [CrossRef]

55. Rupp, D.E.; Mallory, D.B. Corporate social responsibility: Psychological, person- centric, and progressing. Annu. Rev. Organ. Psychol. Organ. Behav. 2015, 2, 211-236. [CrossRef]

56. Pucheta-Martínez, M.C.; Gallego-Álvarez, I. The Role of CEO Power on CSR Reporting: The Moderating Effect of Linking CEO Compensation to Shareholder Return. Sustainability 2021, 13, 3197. [CrossRef]

57. Pucheta-Martínez, M.C.; Gallego-Álvarez, I. An international approach of the relationship between board attributes and the disclosure of corporate social responsibility issues. Corp. Soc. Responsib. Environ. Manag. 2019, 26, 612-627. [CrossRef]

58. Brammer, S.; Millington, A.; Rayton, B. The contribution of corporate social responsibility to organizational commitment. Int. J. Hum. Resour. Manag. 2007, 18, 1701-1719. [CrossRef]

59. Barako, D.; Brown, A. Corporate social reporting and board representation: Evidence from the Kenyan banking sector. J. Manag. Gov. 2008, 12, 309-324. [CrossRef] 
60. Liao, L.; Luo, L.; Tang, Q. Gender diversity, board independence, environmental committee and greenhouse gas disclosure. Br. Account. Rev. 2015, 47, 409-424. [CrossRef]

61. Haniffa, R.; Cooke, T. The impact of culture and governance on corporate social reporting. J. Account. Public Policy 2005, 24, 391-430. [CrossRef]

62. Jizi, M.; Salama, A.; Dixon, R.; Stratling, R. Corporate governance and corporate social responsibility disclosure: Evidence from the US banking sector. J. Bus. Ethics 2014, 125, 601-615. [CrossRef]

63. Chau, G.; Gray, S. Family ownership, board independence and voluntary disclosure: Evidence from Hong Kong. J. Int. Account. Audit. Tax. 2010, 19, 93-109. [CrossRef]

64. Donnelly, R.; Mulcahy, M. Board structure, ownership, and voluntary disclosure in Ireland. Corp. Gov. Int. Rev. 2008, 16, 416-429. [CrossRef]

65. Reverte, C. Determinants of corporate social responsibility disclosure ratings by Spanish listed firms. J. Bus. Ethics 2009, 88, 351-366. [CrossRef]

66. Ali, W.; Frynas, J.; Mahmood, Z. Determinants of corporate social responsibility (CSR) disclosure in developed and developing countries: A literature review. Corp. Soc. Responsib. Environ. Manag. 2017, 24, 273-294. [CrossRef]

67. Wintoki, M.B.; Linck, J.S.; Netter, J.M. Endogeneity and the dynamics of internal corporate governance. J. Financ. Econ. 2012, 105, 581-606. [CrossRef]

68. Archambeault, D.; DeZoort, F.T. Auditor opinion shopping and the audit committee: An analysis of suspicious auditor switches. Int. J. Audit. 2001, 5, 33-52. [CrossRef]

69. Avci, S.; Schipani, C.A.; Seyhun, H. The elusive monitoring function of independent directors. University of Pennsylvania. J. Bus. Law 2018, 21, 235-287.

70. Camilleri, M.A. Environmental, social and governance disclosures in Europe. Sustain. Account. Manag. Policy J. 2015, 6, $224-242$. [CrossRef]

71. Camilleri, M.A. Theoretical insights on integrated reporting: The inclusion of non-financial capitals in corporate disclosures. Corp. Commun. Int. J. 2018, 23, 567-581. [CrossRef] 